\title{
IMPORTANCE OF PUBLIC WAREHOUSE SYSTEM FOR FINANCING AGRIBUSINESS SECTOR ${ }^{1}$
}

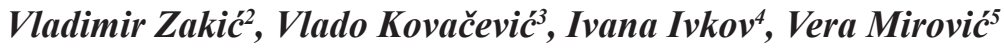 \\ Summary
}

The aim of this study was to determine the economic viability of the use of warehouse receipts for the storage of wheat and corn, based on the analysis of trends in product prices, storage costs in public warehouses and interest rate of loans against warehouse receipts.

Agricultural producers are urged to sell grain at the harvest time when the price of agricultural products is usually lowest, mostly because of their needs for financial sources. Instead of selling products, farmers can store them in the public warehouses and use shorttime financing by lending against warehouse receipt with usually lowest interest rate. In following months, farmers can sell products at higher price and repay short-term loan.

This study showed that strategy of using public warehouses and postponing the sale of grains after harvest is profitable strategy for agricultural producers.

Key words: commodity exchange, public warehouse, warehouse receipt, short term loans.

JEL: $Q 13, Q 14, G 18$

1 This paper is a result of the research projects No. 179028 - "Rural labor market and rural economy of Serbia - Income diversification as a tool to overcome rural poverty", financed by the Ministry of Education and Science of the Republic of Serbia.

2 Vladimir Zakić, Ph.D., Assistant Professor, University of Belgrade - Faculty of Agriculture, Nemanjina Street no. 6, 11080 Zemun, Serbia, Phone: +381 63313 234, E-mail: zakic@agrif.bg.ac.rs

3 Vlado Kovačević, Ph.D., Indemnity Fund of the Republic of Serbia, Nemanjina Street no. 22-26, 11000 Beograd, Serbia, Phone: +381 646581 519, E-mail: vlado.kovacevic@kompenzacionifond.gov.rs

4 Ivana Ivkov, B.Sc., Ministry of Agriculture, Forestry and Water Management of the Republic of Serbia, Nemanjina Street no. 22-26, 11000 Beograd, Serbia, Phone: +381 64125 30 34, E-mail: ivana.ivkov@minpolj.gov.rs

5 Vera Mirović, M.Sc., Lecturer, Higher School of Professional Business Studies, Vladimira Perića Valtera Street no. 4, 21000 Novi Sad, Serbia, Phone: +381 2148540 00, E-mail: veramirovicns@gmail.com

EP 2014 (61) 4 (929-943) 


\section{Introduction}

The case study on importance of public warehouse is done in Serbia, which established fully operational system with:

- Licensing of public warehouse.

- Special unit in the Ministry of Agriculture in charge of public warehouse inspection.

- Indemnity Fund in charge of compensation of grain owner/warehouse receipt holder in case of public warehouse failure.

Beside public warehouses, Serbia also has non-licensed warehouses for agricultural products and these two systems are functioning in parallel and can be compared (Stevanović et al., 2012). As grain prices in Serbia closely correlate with world grain prices, this study can be useful for neighbouring countries with sufficient grain production level, especially for Romania and Croatia, but also for all other countries with similar grain storage costs, interest rates and grain prices. ${ }^{6}$ There are also some new approaches to crop insurance (before harvest) which are used in USA and Canada, such is index insurance. This group of insurance methods is interesting because it is based on the data related to a certain region or administrative unit, while most insurance systems are related to the results of the individual farms (Marković et al., 2013).

The most common questions in countries without public warehouses systems are the following: Do we need public warehouse system? Is it necessary to establish public warehouse system with all three components? Should the warehouse receipts system be embedded in the legislation or contractual relations between the interested parties are sufficient?

The experience of USA, Canada, majority of EU countries, Ukraine, Serbia etc. shows that fully functional warehouse receipts system is very beneficial for the agribusiness sector.

The warehouse receipts systems with all the supporting structures in place has been proven in practice to be more efficient compared with partly established systems (Munćan et al., 2011). If possible, countries opting for introduction of the system should have:

- Licensing body and licensing procedures for warehouses in order to obtain public warehouses license.

- Special controlling body in charge of controlling public warehouse.

- Guarantee structure (such as Indemnity Fund) needs to be established to reimburse the grain owners/warehouse receipts holder if public warehouse cannot deliver grain to the owner. It is important to have out-of-court procedure for compensation (Hollinger et al., 2009).

6 Romania has established system of public warehouses without Indemnity fond and system need to be further developed. Croatia is in the process of developing public warehouse system. Hungary has public warehouse system that doesn't make distinction between industrial and agricultural storage. Macedonia, $\mathrm{BiH}$ and Montenegro have no sufficient volume of grain productions and development of public warehouses could not be recommended. 
If the system is not based on all three components, like it was in the case of Romania, players in the system will not have enough trust: when landing against warehouse receipts banks will be reluctant or interest rate will be higher, traders will have doubt that the grain will be delivered from warehouses and avoid trading with warehouse receipts etc. Development of warehouse receipts is also an essential base for futures and option markets, because warehouse receipts are needed for futures contracts delivery (Coulter and Onumah, 2002).

In Table 1 is shown difference between non-licensed storage which have operated for decades and new public warehouses.

Table 1. Comparative analysis of public warehouses and common non-licensed warehouses

\begin{tabular}{|c|c|c|}
\hline Indicator & Common warehouse & Public warehouse \\
\hline $\begin{array}{l}\text { Insurance of stored agricultural } \\
\text { product }\end{array}$ & Not required & Obligatory \\
\hline License for operation & Not required & Obligatory \\
\hline $\begin{array}{l}\text { Compensation of funds in the } \\
\text { case of goods cannot be taken } \\
\text { from warehouse }\end{array}$ & None & Indemnity fund \\
\hline Products that can be stored & $\begin{array}{l}\text { All types of industrial and } \\
\text { agricultural products }\end{array}$ & $\begin{array}{l}\text { Certain types of agricultural } \\
\text { products }\end{array}$ \\
\hline System of warehouse monitoring & None & Special inspection service \\
\hline
\end{tabular}

Source: Authors' opinion.

There were several attempts to create private public warehouse systems, like in Russia, Kazakhstan, Turkey, mostly from banks and commodity exchanges, but without success (Belozertsov et al., 2011). Recommendation can be given that public warehouse system is needed to be established through national legislation, while licensing and controlling function has to be done by government.

\section{The benefits of the use of warehouse receipts for agricultural sector}

The public warehouse system is based on the licensing of warehouses for grains and oilseeds. To obtain a license, a warehouse must meet the requirements in terms of equipment and facilities and show positive business performance in the previous accounting period, including a sufficient level of a free capital. A public warehouse may issue a warehouse receipt for its own stored goods or for the goods of a third party, as proof of storage ${ }^{7}$.

The warehouse receipt can be used as collateral (Vasiljević and Zakić, 2006) for obtaining short-term loans, which typically have a lower interest rate compared to other short-term loans (Scheme 1). The warehouse receipt can be sold and will typically generate higher prices than the same product sold with other proof of storage (Back et al., 2013).

7 In many warehouse systems, public warehouses are prohibited of issuing warehouse receipts for their own goods. Serbia is allowing this action and this can be recommended for all other systems.

EP 2014 (61) 4 (929-943) 
Scheme 1. Model of lending against warehouse receipt

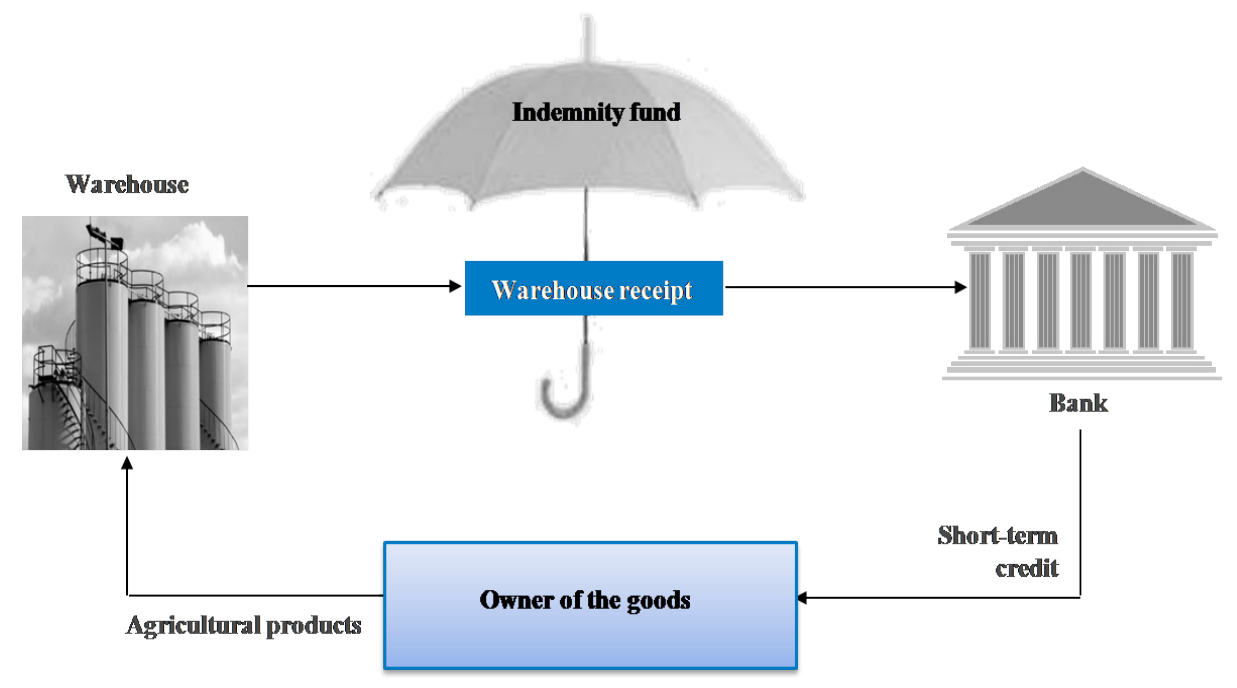

Source: Indemnity Fund of the Republic of Serbia.

Besides being the collateral for obtaining traditional short-term loans, warehouse receipt could also be used for repurchase agreement. Repurchase agreement is an agreement on the sale of securities with a commitment to repurchase them at a specified period and at a fixed price (Mirović and Bolesnikov, 2013). The seller of warehouse receipt (farmer) agrees to repurchase them from the buyer (bank) in predefined period and price.

The benefits of warehouse receipts such as a better price for goods stored in a public warehouse and the acceptance as collateral by commercial banks are the result of the confidence that banks and traders have in the system (Kannapiran, 2000). This confidence is derived form so-called "three rounds of safety" that are built into the system:

1. Only a first class warehouse with appropriate financial indicators and equipment can be licensed.

2. A special inspection service within the Ministry of Agriculture monitors the goods stored in public warehouses.

3. Indemnity Fund which, in the event that the owner of the goods cannot get the products from the public warehouse, indemnify the owner within five days through an out-of-court procedure.

One of the milestones of the public warehouse system is the fact that the Indemnity Fund has separate funds intended for compensation to owners of different types of products.

After establishment of public warehouse system, it is important to have close cooperation with the National bank. In Serbian example, the National Bank of Serbia (NBS) has designated a "sufficient credit rating" for loans against warehouse receipts. This decision has had two effects. Firstly, when lending against warehouse receipts, banks must pay only a 5\% deposit 
to NBS. Secondly, the NBS' decision sent a signal to commercial banks that the warehouse receipt is a first-class commodity security.

Subsidies aimed at reducing interest rates for loan against warehouse receipts are also important element, especially during the first years of the establishment of the system (Vasiljevic and Zakic, 2006). This approach could help banks to gain confidence in warehouse receipts as collateral. EBRD supported three banks in Serbia for loans against warehouse receipts with 50,000,000 EUR throughout risk-share program. Subsidies of storage costs in the public warehouses, especially in the beginning phase, are another important element of support. Based on the Serbian and Bulgarian experience, subsidies have to be higher for the better quality products.

The practice in most countries with public warehouses is to introduce a system of subsidies for storage costs that would support the development of the system in the first few years. In addition, the issue of public warehouses and warehouse receipts are of national importance for the storage of strategic commodity reserves, especially for corn and wheat. In that sense, the following two measures could be recommended for further development of public warehouses: (1) subsidies to storage costs in public warehouses; (2) subsidies to grading equipment needed for grain classification.

Such subsidies would help generate additional interest of new participants and further develop the system (Tilton, 2010). Furthermore, by subsidizing storage in public warehouses in such a way that higher quality products are favoured with higher subsidies, farmers would have an additional interest in producing higher quality goods. Subsidizing equipment for rapid measurement of the protein level in wheat would allow quality classification of wheat. As in other transition countries, it is expected that these two measures could provide an indirect positive effect on improving the quality of wheat (Roache, 2008). That is primarily because producers will be able to sort wheat, to receive higher subsidies for better quality and a better price for their product (Zakić and Kovačević, 2012). Until now, the quality of wheat has not been determined and farmers have usually been paid on the basis of visual characteristics of their wheat, so there has been no economic interest to invest in quality that could not be determined and paid.

It is recommended to develop an electronic warehouse system. Most EU countries are using warehouse receipts in paper form. Advantages of electronic warehouse receipts vs. paper warehouse receipts are:

- Electronic system is safer because public warehouse will be allowed to issue warehouse receipts up to the licensed capacity (electronic system will stop issuing the warehouse receipt for any quantity over the licensed capacity), while in paper form public warehouse can issue warehouse receipts in quantity greater than the licensed capacity. In this manner, the electronic system would increase the overall safety and the lower amount of funds in the Indemnity Fund would be necessary.

- Banks will be allowed to enter in the electronic warehouse system and put the collateral on warehouse when lending against warehouse receipt. Procedure for banks are less 
time consuming (for receipts in paper form banks need to send query to warehouse by fax and when the collateral is established, again need to send fax to warehouse to inform that collateral is established on warehouse receipt etc.) and more secure which leads to lower interest rates.

- Commodity exchanges will have direct links and trading orders could be sent in electronic form. Paper warehouse receipts need to be sent to the commodity exchange by mail. Trading order in case of electronic warehouse receipts can be submitted with local brokerage firms.

- There is no need for public warehouse to purchase costly blank paper warehouses receipts and dairies for keeping public warehouse receipts records, so the overall system would be less expensive.

\section{Methodology and data sources}

Based on the nature of the research, authors used different scientific methods applied in the social sciences: case study approach (using examples), method of interview with relevant experts in the field of establishing public warehouse system, statistical methods in analyzing the collected data received from Commodity exchange Novi Sad (grain prices in Serbia closely correlate with world grain prices).

\section{Econometrical model}

In this article, cost-effectiveness of the use of warehouse receipts is made for wheat and corn. Analysis is based on two scenarios. Under the first scenario, an agricultural product is sold immediately after harvest when the prices are typically lowest. This is compared to scenario two when the agricultural product is stored in the public warehouse and sold later in the year when the price is higher. Wheat is analyzed in the period from July to June the following year, while maize covers the period from October to September.

The following parameters are used in the analysis:

$$
\begin{gathered}
K=\frac{\left(\left(P_{2008}-C_{2008}\right)+\left(P_{2009-} C_{2009}\right)+\left(P_{2010-} C_{2010}\right)+\left(P_{2011-} C_{2011}\right)+\left(P_{2012}-C m_{2012}\right)\right) / Y}{P S} \\
C=\left(V^{*}(I+S)\right) * N
\end{gathered}
$$

$\mathbf{K}$ - Coefficient of profitability of storing products, calculated for each month.

C - Cost of grain storage and interest rate on loan in euros/t, calculated for each month.

$\mathbf{V}$ - Product' value in euros/t.

$\mathbf{S}$ - Storage costs. In the Serbian practice, storage services are paid at the time of taking goods from the warehouse and calculated as $1 \%$ of value of goods /monthly (storage cost calculation is based just on specific market price in the month when goods are taken from the warehouse). 
$\mathbf{N}$ - Number of months that the grain is stored.

$\mathbf{Y}$ - Number of year in observed period.

$\mathbf{P}$ - Price at the specific month of sale.

Ps - Average price for observed period at the harvest month (for wheat it is July, for corn it is October).

$$
I=I w^{*} T+I o *(1-T)
$$

I-Average interest rate.

Iw - Loan interest rate against warehouse receipt is calculated on the basis of $0.38 \%$ (simple) interest rate per month. ${ }^{8}$

T - Percentage of current warehouse receipt' grain value for which banks are approving loan - calculated on the basis of $70 \%{ }^{9}$

Io - Loan interest rate on sum which is not covered from loan against warehouse receipt. In order to get financed on full sum that can be received by selling at the harvest time. According to this calculation $30 \%$ of that sum needs to be financed throughout regular loans. Interest rate is calculated on the basis of $0.65 \%$ (simple) interest rate per month. ${ }^{10}$

According to calculation, average interest rate (I) used in the calculation is $0.46 \%$ (simple) interest rate per month

Coefficient of profitability of storing products $(\mathrm{K})$ shows the relation between prices of grain within 5 years period deduct by cost of storage and interest rates for each month and average grain price at the harvest time. $\mathrm{K}$ coefficient has to have value more than one in order to recommend storage instead of sale at harvest time. If this coefficient is less than 1 , than storage can not be recommended because it will bring losses. Percentage of profit or loss $(\mathrm{R})$ in performing the strategy of storing the agricultural product in public warehouse and financing by use warehouse receipts as collateral for short term loan, instead of selling product at harvest time can be calculated:

$$
R=(K-1) * 100 \%
$$

\section{Empirical study: cost-benefit analysis of the use of warehouse receipts for wheat}

The average monthly prices of wheat for the period 2007-2012 are given in Table 2. In $2007 / 2008$ the price of wheat successively grew slowly until the next harvest.

8 Authors estimation based on consultations with commercial banks.

9 Authors estimation based on consultations with commercial banks.

10 Authors estimation based on consultations with commercial banks.

EP 2014 (61) 4 (929-943) 
Table 2. Average monthly wheat price (EUR/t)

\begin{tabular}{|c|c|c|c|c|c|}
\hline \multirow{2}{*}{ Month } & \multicolumn{5}{|c|}{ Average monthly wheat price (EUR/t) } \\
\cline { 2 - 6 } & $\mathbf{2 0 0 7 / 0 8}$ & $\mathbf{2 0 0 8 / 0 9}$ & $\mathbf{2 0 0 9 / 1 0}$ & $\mathbf{2 0 1 0 / 1 1}$ & $\mathbf{2 0 1 1 / 1 2}$ \\
\hline VII & 165.66 & 195.72 & 99.94 & 127.18 & 169.60 \\
\hline VIII & 181.14 & 189.31 & 96.50 & 163.74 & 170.70 \\
\hline IX & 195.17 & 174.52 & 95.15 & 174.71 & 173.07 \\
\hline X & 236.67 & 163.14 & 93.11 & 182.45 & 175.55 \\
\hline XI & 221.88 & 145.43 & 116.61 & 206.73 & 174.18 \\
\hline XII & 242.90 & 133.22 & 119.72 & 234.89 & 178.52 \\
\hline I & 237.86 & 122.21 & 115.27 & 245.11 & 193.75 \\
\hline II & 273.81 & 128.57 & 112.91 & 271.06 & 200.66 \\
\hline III & 274.05 & 117.12 & 110.36 & 304.94 & 197.46 \\
\hline IV & 283.48 & 106.15 & 106.78 & 296.10 & 193.22 \\
\hline V & 260.27 & 125.56 & 102.21 & 271.19 & 190.89 \\
\hline VI & 244.04 & 132.07 & 102.71 & 234.33 & 201.52 \\
\hline
\end{tabular}

Source: Authors' calculation based on Weighted average, monthly price reports for corn and wheat for period 2007-2012., Commodity Exchange Novi Sad, data received upon request.

In July of 2008/2009 the wheat reached a maximum harvest price of $195.72 \mathrm{EUR} / \mathrm{t}$. In 2009/2010 the lowest price of 99. 94 EUR/t was recorded. During 2009/2010 the prices are at the lowest level of the analyzed period, but at the same time relatively stable. In August $2010 / 2011$ wheat reaches a price that is higher by about $23 \%$ compared to the previous month. In March 2010/2011 the price of wheat is the highest in the analysed period.

Table 3. Cost-benefit analysis of the use of warehouse receipts for wheat in the period from 2007-2012

\begin{tabular}{|c|c|c|c|c|c|c|c|}
\hline \multirow{2}{*}{ Month } & \multicolumn{7}{|c|}{ Financial result (EUR/t) } \\
\cline { 2 - 8 } & $\mathbf{2 0 0 7 / 0 8}$ & $\mathbf{2 0 0 8 / 0 9}$ & $\mathbf{2 0 0 9 / 1 0}$ & $\mathbf{2 0 1 0 / 1 1}$ & $\mathbf{2 0 1 1 / 1 2}$ & K & R (\%) \\
\hline VII & - & - & - & - & - & 1.00 & - \\
\hline VIII & 12.91 & -9.20 & -4.86 & 34.34 & -1.39 & 1.04 & 4 \\
\hline IX & 24.08 & -26.49 & -7.61 & 42.87 & -1.55 & 1.04 & 4 \\
\hline X & 61.62 & -40.18 & -11.00 & 48.04 & -1.66 & 1.07 & 7 \\
\hline XI & 44.30 & -59.71 & 10.17 & 68.94 & -5.51 & 1.08 & 8 \\
\hline XII & 61.28 & -73.66 & 11.50 & 93.04 & -3.91 & 1.12 & 12 \\
\hline I & 53.36 & -86.24 & 5.66 & 99.71 & 7.84 & 1.11 & 11 \\
\hline II & 83.65 & -82.45 & 1.85 & 120.81 & 11.55 & 1.18 & 18 \\
\hline III & 80.37 & -95.17 & -2.09 & 148.68 & 5.82 & 1.18 & 18 \\
\hline IV & 85.45 & -107.23 & -6.91 & 137.01 & -0.79 & 1.14 & 14 \\
\hline V & 60.96 & -91.72 & -12.55 & 111.04 & -5.60 & 1.07 & 7 \\
\hline VI & 43.15 & -88.08 & -13.59 & 74.94 & 1.17 & 1.02 & 2 \\
\hline
\end{tabular}

Source: Authors' calculation based on Weighted average, monthly price reports for corn and wheat for period 2007-2012., Commodity Exchange Novi Sad, data received upon request.

According to the Table 3, the use of strategy of storing the agricultural product in public warehouse and financing by the use of warehouse receipts as collateral for short term loan, instead of selling product at harvest time, performed positive financial results for agricultural 
producers. Next step in this study is to analyze specific results of postponing the sale by each month for the observed period of 2007/2008, 2008/2009, 2009/2010, 2011/2012:

1. August sale will bring better wheat price for producers. $R$ percentage for this month is $4 \%$ (or $\mathrm{K}$ coefficient 1.04) which means that the profit will be increased compared to sale at harvest. This is one of the months with lowest $\mathrm{K}$ coefficient, therefore cannot be recommended for product sale. This is expectable because in the first month after harvest there is sufficient supply of wheat and prices are slowly rising.

2. September will bring better wheat price for producers (same results as the previous month), but $\mathrm{R}$ percentage for this month is still $4 \%$. This is also one of the months with lowest $\mathrm{R}$ percentage, therefore product sale can not be recommended.

3. October has $\mathrm{R}$ percentage of $7 \%$ which mean that the profit will be increased compared to sale at harvest. The $\mathrm{R}$ percentage is still moderate, therefore product sale can not be recommended.

4. November has $\mathrm{R}$ percentage of $8 \%$ (similar as the previous month).

5. December has $\mathrm{R}$ percentage of $12 \%$, because demand for wheat start to grow. $\mathrm{R}$ percentage is higher than before and sale in December can be considered.

6. January has R percentage of $11 \%$ - slightly lower than in the previous month. Sale should be postponed.

7. February has $\mathrm{R}$ percentage of $18 \%$ - that is one of two best months for sale and paying of loan against warehouse receipt. Sale in February is highly recommended.

8. March has $\mathrm{R}$ percentage equal with previous month. Sale is highly recommended.

9. April has R percentage of $14 \%$. Sale in April can be recommended, as a third best month for sale.

10. May has $\mathrm{R}$ percentage of $7 \%$, therefore product sale can not be recommended.

11. June has $\mathrm{R}$ by percentage of $2 \%$, therefore product sale also can not be recommended. 
Figure 1. K - coefficient for wheat in the period of 2007/2012

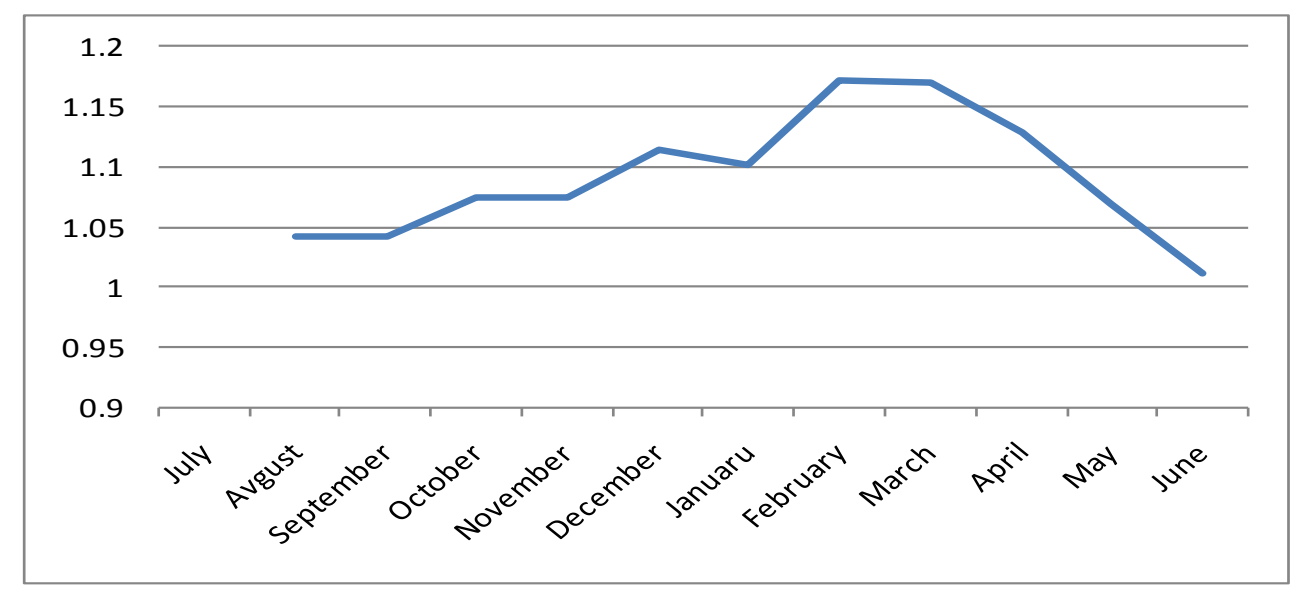

Source: Authors' calculation based on Weighted average, monthly price reports for corn and wheat for period 2007-2012., Commodity Exchange Novi Sad, data received upon request.

\section{Empirical study: cost-benefit analysis of the use of warehouse receipts for corn}

Average monthly prices for corn in the period of 2007-2012 are given in Table 4. During the reporting period, there were very different movements in the monthly price of corn. Corn prices harvested in 2008 at the harvest reached a maximum of 219.99 EUR/t. During this economic year, the variability in prices did not exceed $6 \%$ from the average until August, when prices fell sharply by about $30 \%$ compared to the previous month.

Table 4. Average monthly price of corn (EUR/t)

\begin{tabular}{|c|c|c|c|c|c|}
\hline \multirow{2}{*}{ Month } & \multicolumn{5}{|c|}{ Average monthly corn price (EUR/t) } \\
\cline { 2 - 6 } & $\mathbf{2 0 0 7 / 0 8}$ & $\mathbf{2 0 0 8 / 0 9}$ & $\mathbf{2 0 0 9 / 1 0}$ & $\mathbf{2 0 1 0 / 1 1}$ & $\mathbf{2 0 1 1 / 1 2}$ \\
\hline X & 219.99 & 89.84 & 89.47 & 145.31 & 151.76 \\
\hline XI & 183.45 & 82.62 & 103.84 & 151.22 & 148.79 \\
\hline XII & 192.62 & 84.00 & 105.33 & 174.51 & 144.88 \\
\hline I & 194.29 & 90.12 & 111.82 & 202.76 & 160.00 \\
\hline II & 182.65 & 96.80 & 110.10 & 200.92 & 167.90 \\
\hline III & 176.70 & 88.00 & 108.06 & 211.50 & 168.10 \\
\hline IV & 187.38 & 95.76 & 116.55 & 211.58 & 174.68 \\
\hline V & 181.92 & 114.36 & 116.32 & 201.69 & 171.34 \\
\hline VI & 189.87 & 125.35 & 129.06 & 197.44 & 169.57 \\
\hline VII & 185.69 & 118.08 & 158.62 & 219.63 & 209.42 \\
\hline VIII & 133.83 & 98.97 & 178.78 & 195.01 & 218.49 \\
\hline IX & 114.58 & 83.22 & 169.81 & 166.45 & 232.98 \\
\hline
\end{tabular}

Source: Authors' calculation based on Weighted average, monthly price reports for corn and wheat for period 2007-2012., Commodity Exchange Novi Sad, data received upon request. 
Profitability of the use of warehouse receipts in the period from 2007-2012 is shown in Table 5.

Table 5. Cost-benefit analysis of use of warehouse receipts for corn in the period from 2007-2012

\begin{tabular}{|c|c|c|c|c|c|c|c|}
\hline \multirow{2}{*}{ Month } & \multicolumn{7}{|c|}{ Financial result (EUR/t) } \\
\cline { 2 - 8 } & $\mathbf{2 0 0 7 / 0 8}$ & $\mathbf{2 0 0 8 / 0 9}$ & $\mathbf{2 0 0 9 / 1 0}$ & $\mathbf{2 0 1 0 / 1 1}$ & $\mathbf{2 0 1 1 / 1 2}$ & K & R (\%) \\
\hline X & - & - & - & - & - & 1.00 & - \\
\hline XI & -39.39 & -8.46 & 12.92 & 3.73 & -5.16 & 0.95 & -5 \\
\hline XII & -33.25 & -8.35 & 12.93 & 24.37 & -11.17 & 0.98 & -2 \\
\hline I & -34.56 & -3.66 & 17.76 & 49.36 & 1.35 & 1.04 & 4 \\
\hline II & -48.69 & 1.43 & 14.58 & 44.90 & 6.63 & 1.03 & 3 \\
\hline III & -57.18 & -8.31 & 11.13 & 52.27 & 4.44 & 1.00 & - \\
\hline IV & -49.92 & -2.31 & 17.62 & 49.56 & 8.25 & 1.03 & 3 \\
\hline V & -57.89 & 13.62 & 15.83 & 37.58 & 2.70 & 1.02 & 2 \\
\hline VI & -53.41 & 22.18 & 25.97 & 30.99 & -1.34 & 1.04 & 4 \\
\hline VII & -60.12 & 13.89 & 51.17 & 48.54 & 32.53 & 1.12 & 12 \\
\hline VIII & -10.66 & -4.90 & 67.32 & 23.51 & 37.90 & 1.02 & 2 \\
\hline IX & -129.15 & -20.32 & 57.13 & -4.52 & 47.91 & 0.93 & -7 \\
\hline
\end{tabular}

Source: Authors' calculation based on Weighted average, monthly price reports for corn and wheat for period 2007-2012., Commodity Exchange Novi Sad, data received upon request.

The periods 2009/2010, 2010/2011 and 2011/2012 were typical in which the price of corn rose from the beginning of the new harvest. In these years, the use of commodity securities brought high additional profits.

According to the Table 5, the use of strategy of storing the agricultural product in public warehouse and financing by use warehouse receipts as collateral for short term loan, could give positive results for agricultural producers in certain months. Like in previous case of wheat, next step is to analyze specific results of postponing the sale by each month for the observed period of 2007/2008, 2008/2009, 2009/2010, 2011/2012:

1. November is month when the sale of corn will bring loss. $R$ percentage for this month is $-5 \%$. This is expectable because in the first month after harvest there is sufficient supply of corn. Sale can not be recommended.

2. December will bring better corn price for producers, but $\mathrm{R}$ percentage is still negative $(-2 \%)$. Therefore, product sale can not be recommended.

3. January has $\mathrm{R}$ percentage of $4 \%$. Sale can be recommended in this period, especially when compared with trends in following months.

4. February has $\mathrm{R}$ percentage of $3 \%$ (similar as previous month). Sale can also be recommended in this period.

5. March has barely positive $R$ percentage ( $\mathrm{K}$ coefficient is 1.0034$)$. Sale can not be recommended. 
6. April has R percentage of $3 \%$ and the corn prices are still rising. Sale in April can also be recommended.

7. May has R percentage slightly lower than in the previous month (2\%). Sale in May can not be recommended.

8. June has R percentage of $4 \%$, but sale should be postponed for July.

9. July is the best month for corn sale and paying of a loan against the warehouse receipt. $\mathrm{R}$ percentage is highest (12\%). Sale is highly recommended. Since the average price is dropping producers should not to wait any longer.

10.August has $\mathrm{R}$ percentage of $2 \%$. This is final period for any positive result.

11. September is the worst month for producers. $R$ percentage is $-7 \%$.

Figure 2 graphically shows K coefficient trends for corn for observed average period of one economic year.

Figure 2. K - coefficient for corn in the period of 2007/2012

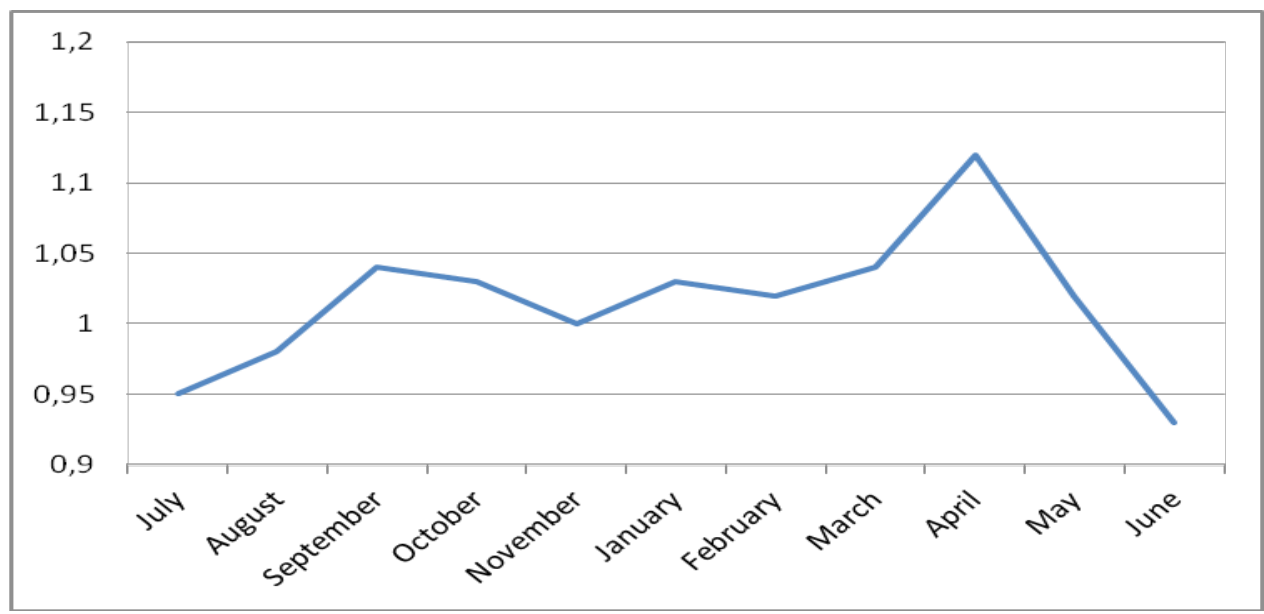

Source: Authors' calculation based on Weighted average, monthly price reports for corn and wheat for period 2007-2012., Commodity Exchange Novi Sad, data received upon request.

\section{Conclusion}

On the basis of this research, the conclusions can be drawn that strategy of using public warehouses and postponing the sale of grains after harvest is profitable strategy for agricultural producers.

By postponing the wheat sale farmers could increase profit by $2-18 \%$. Best months for wheat sale and paying back the loans against warehouse receipts are February and March. It could be concluded that strategies of using warehouse receipts for financing generates much better results for wheat compared to corn.

By postponing the corn sale farmers could increase profit up to $12 \%$, but sale in the months 
close to new harvest can generate loss up to $7 \%$. A best month for wheat sale and paying back the loans against warehouse receipts is July.

Finally, the research results point out the great significance of public warehouse system for financing agriculture. For development or improvements of the existing public warehouse system, several recommendations could be given:

1. Establishment of public warehouse with all three components: licensing procedures, inspection body and indemnity fund.

2. Development of public warehouse system just for agricultural products. Public warehouse system for industrial products has to be established separately.

3. System has to be based on legislation rather than the private contracts among the parties in the system.

4. It is important when developing system to cooperate with National bank in order to provide best credit rating for loans against warehouse receipts.

5. It is of great importance to introduce electronic warehouse receipts.

6. Practice in the most countries with a public warehouse system is to introduce a system of subsidies that would support the development of the system in the first few years.

\section{References}

1. Back, J., Prokopczuk, M., Rudolf, M. (2013): Seasonality and the valuation of commodity options, Journal of Banking \& Finance, no. 37, Issue 2, Elsevier, pp. 273-290, Amsterdam.

2. Belozertsov, A., Rutten, L., Hollinger, F. (2011): Commodity exchange in Europe and Central Asia a means of management of price risk, Working paper, no. 5, FAO/World Bank, Rome, pp. 3-17.

3. Coulter, J., Onumah, G. (2002): The role of warehouse receipt systems in enhanced commodity marketing and rural livelihoods in Africa, Food Policy, vol. 27, no. 2, pp. 319337.

4. Hollinger, F., Rutten, L. (2009): The Use of Warehouse Receipt Finance in Agriculture in ECA Countries, FAO World Bank Cooperative Programme/FAO EBRD Cooperative Programme, pp. 3-24, available at: http://www.eastagri.org/files/FAO EBRD-WarehouseReceipt-Financing.pdf,

5. Indemnity fund of the Republic of Serbia, available at: www.kompenzacionifond.gov.rs

6. Kannapiran, C. (2000): Commodity price stabilisation: Macroeconomic impacts and policy options, Agricultural Economics, no. 23, Elsevier, Amsterdam.

7. Marković, T., Ivanović, S., Todorović, S. (2013): Reduction in revenue volatility in maize production applying the indirect-index insurance, Economics of Agriculture, no. 3, vol. 60, pp. 445-454, IAE Belgrade. 
8. Mirović, V. and Bolesnikov, D. (2013): Application of Asset Securitization in Financing Agriculture in Serbia, Economics of Agriculture, no. 3, vol. 60, pp. 551-564, IAE Belgrade.

9. Munćan, P., Božić, B., Bogdanov, N. (2011): Economic efficiency offield crop production on family farms in the autonomous province of Vojvodina, Economics of Agriculture, no. 1, vol. 57, pp. 15-25, IAE Belgrade.

10. Roache K., (2008): Commodities and the Market Price of Risk, WP 08/221, International Monetary Fund.

11. Stevanović, S., Đorović, M., Milanović, M. (2012): The development of the market production of cereals in Serbia: example wheat and corn, Economics of Agriculture, vol. 58, no. 4, pp. 617-633, IAE Belgrade.

12. The Law on Public Warehouses for agricultural products, Official Gazette of the Republic of Serbia, no. 41/09.

13. Vasiljevic, Z., Zakic, V. (2006): Finansiranje agroprivrede Srbije u uslovima tranzicije, Ekonomski vidici, vol. 11, br. 2, str. 341-353, Društvo ekonomista, Beograd

14. Weighted average, monthly price reports for corn and wheat for period 2007-2012., Commodity exchange Novi Sad, Serbia, Available at: http://www.proberza.co.rs/

15.Zakić, V., Kovačević, V. (2012): Importance of commodity derivatives for Serbian agricultural enterprises risk management, Proceedings, International Scientific Meeting Sustainable agriculture and rural development in terms of the republic of Serbia strategic goals realization within the Danube region, Tara, 6-8 December, pp. 907-924, IAE, Belgrade.

16. Tilton, J. (2010): Investor demand and spot commodity prices, Resources Policy, no. 36, Elsevier, Amsterdam. 


\title{
ZNAČAJ SISTEMA JAVNIH SKLADIŠTA ZA FINANSIRANJE AGRO-BIZNIS SEKTORA
}

\author{
Vladimir Zakić11, Vlado Kovačević ${ }^{12}$, Ivana Ivkov ${ }^{13}$, Vera Mirovic ${ }^{14}$
}

\begin{abstract}
Rezime
Cilj ovog rada je da se utvrdi ekonomska isplatljivost korišćenja javnih skladišta za skladištenje pšenice i kukuruza na osnovu analize kretanja cena proizvoda, troškova skladištenja i kamatne stope na kredite koji kao zalogu imaju robni zapis.

Poljoprivredni proizvođači su usled potreba za finansijskim sredstvima često primorani da prodaju žitarice odmah nakon žetve kada je cena po pravilu najniža. Umesto prodaje, poljoprivrednici mogu uskladištiti proizvod u javnim skladištima i koristiti robni zapis kao obezbeđenje za kratkoročni kredit koji često ima nisku kamatnu stopu. U mesecima nakon žetve poljoprivrednik prodaje robu po višoj ceni i vraća kredit.

Ovaj rad je ukazao na profitabilnost strategije skladištenja robe u javim skladištima $i$ odlaganje prodaje proizvoda za period nakon žetve.
\end{abstract}

Ključne reči: robna berza, javno skladište, robni zapis, kratkoročni kredit

11 Doc. dr Vladimir Zakić, Univerzitet u Beogradu - Poljoprivredni fakultet, Nemanjina 6, 11080 Zemun, Srbija, Telefon: +381 63313 234, E-mail: zakic@agrif.bg.ac.rs

12 Dr Vlado Kovačević, Kompenzacioni fond Republike Srbije, Nemanjina 22-26, 11000 Beograd, Srbija, Telefon: +381 646581 519, E-mail: vlado.kovacevic@kompenzacionifond.gov.rs

13 Ivana Ivkov, dipl. inž., Ministarstvo poljoprivrede i zaštite životne sredine Republike Srbije, Nemanjina 22-26, 11000 Beograd, Srbija, Telefon: +381 6412530 34, E-mail: ivana.ivkov@minpolj.gov.rs

14 Mr Vera Mirović, predavač, Visoka poslovna škola strukovnih studija, Vladimira Perića Valtera 4, 21000 Novi Sad, Srbija, Telefon: +381 21485 4000, E-mail: veramirovicns@gmail.com

EP 2014 (61) 4 (929-943) 